\title{
NURSING DIAGNOSES OF PATIENTS IN THE PREOPERATIVE PERIOD OF ESOPHAGEAL SURGERY
}

\author{
Ana Elisa Ricci Lopes ${ }^{1}$ \\ Daniele Acalá Pompeo ${ }^{2}$ \\ Silvia Rita Marin da Silva Canini ${ }^{3}$ \\ Lídia Aparecida Rossi ${ }^{4}$
}

\begin{abstract}
Lopes AER, Pompeo DA, Canini SRMS, Rossi LA. Nursing diagnoses of patients in the preoperative period of esophageal surgery. Rev Latino-am Enfermagem 2009 janeiro-fevereiro; 17(1):66-73.

This study aimed to identify and analyze the nursing diagnoses of patients in the preoperative period of esophageal surgeries. Data were collected by means of an instrument, based on Horta's Conceptual Model. The study group consisted of 20 patients hospitalized at the Ribeirão Preto Medical School Hospital das Clínicas, who would undergo esophageal surgery. The patients were submitted to an interview and a physical examination. The nursing diagnoses identified at frequencies of more than 50\% were: impaired swallowing (100\%); risk for infection (100\%); knowledge deficit about disease and perioperative period (95\%), and chronic pain (75\%). These diagnoses were analyzed in view of the related factors, defining characteristics or risk factors, according to the type of diagnosis and the responses to the esophageal disease.
\end{abstract}

DESCRIPTORS: nursing diagnosis; perioperative care; nursing

\section{DIAGNÓSTICOS DE ENFERMERÍA DE PACIENTES EN PERÍODO PRE-OPERATORIO DE CIRUGÍA ESOFÁGICA}

Este estudio tuvo como objetivos identificar y analizar los diagnósticos de enfermería de pacientes en el período pre operatorio de cirugías de esófago. Los datos fueron recolectados por medio de un instrumento fundamentado en el Modelo Conceptual de Horta. El grupo estudiado fue constituido por 20 pacientes internados en el Hospital de las Clínicas de la Facultad de Medicina de Ribeirao Preto, en Brasil, para ser sometidos a cirugía esofágica. Los pacientes fueron sometidos a una entrevista y a un examen físico. Los diagnósticos de enfermería identificados con una frecuencia mayor que 50\% fueron: acción de deglutir perjudicada (100\%), riesgo de infección (100\%), conocimiento deficiente sobre la enfermedad y período peri operatorio (95\%) y dolor crónico (75\%). Esos diagnósticos fueron analizados considerando los factores relacionados, las características de definición o los factores de riesgo, de acuerdo con el tipo de diagnóstico, y las respuestas a la patología esofágica.

DESCRIPTORES: diagnóstico de enfermería; atención perioperativa; enfermería

\section{DIAGNÓSTICOS DE ENFERMAGEM DE PACIENTES EM PERÍODO PRÉ-OPERATÓRIO DE CIRURGIA ESOFÁGICA}

Este estudo teve como objetivos identificar e analisar os diagnósticos de enfermagem de pacientes no período pré-operatório de cirurgias esofágicas. Os dados foram coletados por meio de instrumento fundamentado no Modelo Conceitual de Horta. O grupo estudado foi constituído por 20 pacientes internados no Hospital das Clínicas da Faculdade de Medicina de Ribeirão Preto - Brasil para serem submetidos a cirurgia esofágica. Os pacientes foram submetidos à entrevista e exame físico. Os diagnósticos de enfermagem identificados com freqüência maior que 50\% foram: deglutição prejudicada (100\%), risco para infecção (100\%), conhecimento deficiente sobre a doença e período perioperatório (95\%) e dor crônica (75\%). Esses diagnósticos foram analisados considerando-se os fatores relacionados, as características definidoras ou fatores de risco, de acordo com o tipo de diagnóstico, e as respostas à patologia esofágica.

DESCRITORES: diagnóstico de enfermagem; assistência perioperatória; enfermagem

Escola de Enfermagem de Ribeirão Preto, da Universidade de São Paulo, Centro Colaborador da OMS para o Desenvolvimento da Pesquisa em Enfermagem, Brazil: ${ }^{1}$ Undergraduate student in Nursing, e-mail: anaelisarl@gmail.com; ${ }^{2}$ Master's student, e-mail: dalcala@eerp.usp.br; ${ }^{3}$ Faculty, e-mail: canini@eerp.usp.br; ${ }^{4}$ Associate Professor, e-mail: rizzardo@eerp.usp.br. 


\section{INTRODUCTION}

Perioperative nursing is an expression used to describe a variety of nursing functions associated to surgical experience. The preoperative period corresponds to the first phase of the perioperative period. It begins when the surgical intervention is decided on and ends when the patient is on the operating table. In this phase, the following are performed: guidance regarding the procedures related to the perioperative period and careful patient management according to each type of surgery. The purpose is to identify, solve or alleviate the problems that might possibly interfere in the subsequent periods, i.e. intra- and postoperative periods, and to reduce the risk for complications ${ }^{(1)}$.

The focus of interest of this study is the identification of nursing diagnoses of patients in the preoperative period of esophageal surgery.

The gastrointestinal tract (GI) is the pathway that extends from the mouth, passing through the esophagus, stomach, small and large intestines, to the anus. The esophagus enters the superior mediastinum, in the thoracic cavity, where it lies anterior to the vertebral column and posterior to the trachea and heart. The esophagus' function is to transport food from the mouth to the stomach, which is facilitated by two sphincters: the upper esophageal sphincter, which is located at the junction of the pharynx and the esophagus, and the lower esophageal sphincter, also called esofagogastric sphincter, which is located at the level of the junction of the esophagus and the stomach (esofagogastric junction) ${ }^{(2)}$.

The most common types of esophageal surgeries are: Hiatal herniorrhaphy, Esophagectomy, Cardiomytomy and Serra Dória. Hiatal herniorrhaphy is indicated for patients who have hiatal hernia. It is an abnormal protrusion of any abdominal structure into the abdominal cavity through the esophageal hiatus. The surgery consists in reestablishing the cardioesophageal junction to its correct anatomic position in the abdomen ${ }^{(2)}$.

Esophagectomy involves the excision of all or any part of the esophagus of patients with a cancer diagnosis in this organ. The tumor location and size are determinants of the resection length. It is a major surgery with high rates of morbidity and mortality $(10 \%$ to $40 \%$ ), as the disease is usually diagnosed in late stages, besides the fact that several patients are smokers, heavy drinkers and undernourished.
Moreover, esophageal cancer is the third most frequent cancer among tumors of the digestive system. It usually appears during the sixth decade of life and hardly ever before the age of $30^{(2)}$.

Cardiomyotomy consists in the myotomy of the esofagogastric junction to correct the esophageal obstruction resulting from a cardiospasm. The disease commonly associated to this surgery is achalasia, also known as megaesophagus, which results in failure of esophageal body peristalsis and inability of the lower esophageal sphincter to relax on deglution ${ }^{(2)}$. The main symptoms of achalasia are dysphagia, regurgitation, retrosternal pain, heartburn, sialorrhea and weight $\operatorname{loss}^{(2)}$.

Serra Dória consists in the performance of a wide esofagogastric anastomosis, managing to facilitate esophageal emptying through cardioplasty and Rouxen-Y partial gastrectomy ${ }^{(3)}$.

Nursing diagnoses in specific patient groups have been the focus of a variety of studies; however, few have focused on the diagnoses of preoperative patients, regardless of the surgery. Among the studies found, the most frequent diagnoses were: Risk for infection $(100 \%)$, Risk for ineffective breathing pattern $(66.6 \%)$, Anxiety $(66.6 \%)$ and Risk for aspiration $(63.3 \%)^{(4)}$; Anxiety $(86.6 \%)$, Impaired physical mobility $(3.3 \%)$ and Altered Health maintenance $(3.3 \%)^{(5)}$.

Investigations regarding nursing diagnoses of patients undergoing specific surgical procedures showed usual diagnoses for the surgical situation, and some related to specific surgeries like cardiac surgery: Intolerance to activity, Risk for peripheral neurovascular dysfunction, Risk for infection, Knowledge deficit, Ineffective breathing pattern, Altered cardiopulmonary tissue perfusion, Pain, Altered sexual patterns, and Sleep pattern disturbance ${ }^{(6)}$; Fear, Anxiety, for infection, Knowledge deficit, Intolerance to activity, Risk for deficit in liquid volume, Impairment in skin integrity, Altered sexuality, Sleep pattern disturbance and Spiritual anxiety/distress ${ }^{(7)}$; laryngectomies: Anxiety, Fear, Imbalanced nutrition less than body requirements, Impaired swallowing, Impaired verbal communication, Ineffective therapeutic regimen management, Risk for infection, Risk for caregiver role strain, and Behavior to increase health status ${ }^{(8)}$; surgical correction of the palatal cleft: Knowledge deficit, Disturbed body image, Sleep pattern disturbance, and Impaired swallowing ${ }^{(9)}$. However, studies focusing on nursing diagnoses of patients in the preoperative period of esophageal surgery were not found. 
It is believed that knowledge about health problems of a patient group with common features can drive nursing care, support patient care planning, interventions, in-service training/education/training courses and professional staff training. Nursing diagnosis identification in a group of patients provides knowledge about altered human answers, thus contributing to the development of oriented and individualized nursing interventions.

"Nursing diagnoses common to a group of individuals outlined this group profile, allowing a global guidance of nursing interventions ${ }^{\prime \prime(10)}$.

Therefore, this study aimed to identify and analyze the nursing diagnoses of patients in the preoperative period after esophageal surgeries.

\section{METHODS}

This study was carried out at the Medical and Surgical Units of the University of São Paulo at Ribeirão Preto Medical School Hospital das Clínicas (HCFMRPUSP), which offer 13 beds for gastrointestinal surgery. The study was approved by the local Research Ethics Committee.

For the sake of convenience, the sample consisted of 20 patients older than 18 years, regardless of gender, hospitalized in the above-mentioned hospital facilities to undergo medium or major elective esophageal surgeries and who consented to participate in the study. Written informed consent was obtained from all participants or their authorized representatives. Exclusion criteria were to be in the preoperative period of emergency or urgency esophageal surgeries, impaired verbal communication, presence of mental disorders, refusal to participate in the study, or to be in the preoperative period of surgery to correct caustic stenosis, due to the characteristics presented by this kind of patients.

Data were collected by means of an instrument based on Horta's Conceptual Model, consisting of open and closed questions. Data collection used means like interviews, observation and measurement.

Patients' complementary data were retrieved from the medical records. The instrument consisted of four major items: identification, psychobiological, psychosocial, and psychospiritual needs.

After developing the instrument, face and content validation was performed by three specialists in surgical nursing and nursing diagnoses. The recommendations were accepted, which contributed to refine the instrument. A pretest was also performed with the patients, in which no changes were noticed.

After each data collection, an analysis and synthesis of the obtained data for each patient was performed by means of a diagnostic reasoning process, established in the literature ${ }^{(11)}$. Categorizing the data allowed for the identification of gaps and diverging data. These, when present, determined the need to return to the data collection phase. The categorized data were gathered in order to establish clients' behavior patterns concerning a diagnostic inference ${ }^{(11)}$. These groupings were compared to concepts, models or theories. Based on this comparison, diagnostic hypotheses were established regarding the non-satisfied basic health needs ${ }^{(11-12)}$.

Afterwards, nursing diagnoses were established by the study's first author, based on the North American Nursing Diagnosis Association-II Taxonomy (NANDA) ${ }^{(13)}$, except for the nursing diagnosis of Chronic Pain, which was established based on the interpretation proposed by another author ${ }^{(14)}$, as the diagnosis was more adequate to the patients' clinical picture. Tables were used to register these phases. For each diagnostic inference, corresponding data were registered and a comparison was made with literature and other factors associated to these diagnoses. Tables with the description of the diagnostic reasoning, along with the respective formulated diagnoses and the data collection instrument, were handed over to three registered nurses with extensive experience in nursing diagnosis issues (teaching, care and research), in order to confirm the diagnoses identified by the author or not, or to include new diagnoses. The unconfirmed or new diagnoses were reviewed by the student and her tutor.

\section{RESULTS}

Twenty patients were screened for eligibility, eight men and 12 women. Patients' age ranged from 24 to 75 years. Regarding education, three patients were illiterate, 12 did not complete elementary school, three completed secondary education, and one had a higher education degree.

Of the six patients who presented a medical diagnosis of chagasic megaesophagus, five were born in endemic areas of Chagas Disease.

In relation to the diagnosis prior to surgery, we have found the following diagnoses: six patients with chagasic megaesophagus, three with esophageal 
neoplasia, seven with gastroesophageal reflux, three with idiopathic achalasia, and one with esophageal stenosis and hiatal hernia. The surgeries proposed were as follows: Cardiomyotomy (6), Esophageal (3),
Hiatal hernioplasty (7), Hiatal herniorrhaphy (1), Serra-Dória (2) and Esophagogastrectomy (1).

Table 1 shows the nursing diagnoses of all patients screened.

Table 1 - Diagnostic Categories identified in adult patients in the preoperative period of esophageal surgeries. Ribeirão Preto, 2007

\begin{tabular}{|c|c|c|c|c|c|c|c|c|c|c|c|c|c|c|c|c|c|c|c|c|c|c|}
\hline \multirow{2}{*}{ Diagnostic Category } & \multicolumn{20}{|c|}{ Patients } & \multicolumn{2}{|c|}{ Total } \\
\hline & 1 & 2 & 3 & 4 & 5 & 6 & 7 & 8 & 9 & 10 & 11 & 12 & 13 & 14 & 15 & 16 & 17 & 18 & 19 & 20 & $\mathbf{n}$ & $\%$ \\
\hline Impaired swallowing & $x$ & $x$ & $x$ & $x$ & $x$ & $x$ & $x$ & $x$ & $x$ & $x$ & $x$ & $x$ & $x$ & $x$ & $x$ & $x$ & $x$ & $x$ & $x$ & $x$ & 20 & 100 \\
\hline Risk for infection & $x$ & $x$ & $x$ & $x$ & $x$ & $x$ & $x$ & $x$ & $x$ & $x$ & $x$ & $x$ & $x$ & $x$ & $x$ & $x$ & $x$ & $x$ & $x$ & $x$ & 20 & 100 \\
\hline $\begin{array}{l}\text { Deficient knowledge regarding the } \\
\text { disease and perioperative period }\end{array}$ & $\mathrm{x}$ & $x$ & $x$ & $x$ & $x$ & $x$ & $x$ & $x$ & $x$ & $x$ & $x$ & $x$ & $x$ & - & $x$ & $x$ & $x$ & $x$ & $x$ & $x$ & 19 & 95 \\
\hline Chronic pain & $x$ & $x$ & - & $x$ & $x$ & $x$ & - & $x$ & $x$ & - & $x$ & - & $x$ & $x$ & $x$ & $x$ & $x$ & $x$ & $x$ & $x$ & 16 & 75 \\
\hline $\begin{array}{l}\text { Imbalanced nutrition: Less than body } \\
\text { requirements }\end{array}$ & $x$ & $x$ & - & - & $x$ & - & $x$ & $x$ & $x$ & $x$ & - & - & $x$ & - & - & - & - & - & - & - & 8 & 40 \\
\hline Constipation & $x$ & $x$ & - & - & - & - & $x$ & $x$ & - & $x$ & - & - & $x$ & - & - & - & - & $x$ & - & - & 7 & 35 \\
\hline Nausea & $x$ & $x$ & - & - & - & $x$ & - & - & - & - & - & - & $x$ & - & - & - & $x$ & - & $x$ & $x$ & 7 & 35 \\
\hline $\begin{array}{l}\text { Imbalanced nutrition: More than body } \\
\text { requirements }\end{array}$ & - & - & - & - & - & $x$ & - & - & - & - & $x$ & $x$ & - & - & $x$ & $x$ & - & - & $x$ & - & 6 & 30 \\
\hline Anxiety & - & - & - & - & - & - & - & - & - & - & $x$ & $x$ & $x$ & - & $x$ & - & $x$ & - & - & - & 5 & 25 \\
\hline Impaired skin integrity & - & - & $x$ & - & - & - & - & - & - & - & - & - & - & - & - & - & - & - & - & - & 1 & 5 \\
\hline Disturbed sensory perception & - & - & - & - & $x$ & - & - & - & - & - & - & - & - & - & - & - & - & - & - & - & 1 & 5 \\
\hline Risk for aspiration & - & - & - & - & - & - & - & $x$ & - & - & - & - & - & - & - & - & - & - & - & - & 1 & 5 \\
\hline Risk for trauma & - & - & - & - & - & - & - & - & - & $x$ & - & - & - & - & - & - & - & - & - & - & 1 & 5 \\
\hline Impaired walking & - & - & - & - & - & - & - & - & - & - & $x$ & - & - & - & - & - & - & - & - & - & 1 & 5 \\
\hline Altered sleep & - & - & - & - & - & - & - & - & - & - & - & - & - & $x$ & - & - & - & - & - & - & 1 & 5 \\
\hline Acute pain & - & - & - & - & - & - & $x$ & - & - & - & - & - & - & - & - & - & - & - & - & - & 1 & 5 \\
\hline
\end{tabular}

$\mathrm{x}=$ indicates presence of nursing diagnosis

- = indicates absence of nursing diagnosis.

Sixteen distinct nursing diagnoses were identified. Of these, 13 were real diagnoses and three were risk diagnoses. Of these, 13 refer to the psychobiological needs and three to the psychosocial needs.

The diagnoses of Impaired swallowing and Risk for infection presented $100 \%$ of frequency. The diagnosis of Deficient knowledge regarding the disease and perioperative period was observed in 19 of the 20 patients. The diagnosis of Chronic pain was observed in 16 patients and that of Impaired nutrition: less the body requirements in eight patients.

Table 2 presents the real diagnoses with the related factors identified in the study patients.

Among the 20 patients who presented the diagnosis of Impaired swallowing, the related factors were achalasia (9), which was identified in patients with medical diagnosis of chagasic and idiopathic megaesophagus, and esophageal defects (11), identified in 11 patients who presented other esophageal diseases.
Table 2 - Related factors of each real diagnosis identified in adult patients in the preoperative period of esophageal surgeries. Ribeirão Preto, 2007

\begin{tabular}{|c|c|}
\hline Diagnostic Category & Related Factors \\
\hline \multirow{2}{*}{ Impaired swallowing } & Esophageal defects \\
\hline & Achalasia \\
\hline \multirow{2}{*}{$\begin{array}{l}\text { Deficient knowledge regarding the } \\
\text { disease and perioperative period }\end{array}$} & Lack of exposition \\
\hline & Cognitive limitation \\
\hline Anxiety & $\begin{array}{l}\text { Threat to or change in health } \\
\text { status }\end{array}$ \\
\hline \multirow[t]{3}{*}{$\begin{array}{l}\text { Impaired nutrition: less than body } \\
\text { requirements }\end{array}$} & $\begin{array}{l}\text { Impaired swallowing caused by } \\
\text { biological factors }\end{array}$ \\
\hline & Irregular bowel habits \\
\hline & Deficient food habits \\
\hline \multirow[t]{3}{*}{ Constipation } & Deficient fiber intake \\
\hline & Deficient liquid intake \\
\hline & Reduced GI tract motility \\
\hline Nausea & Esophageal disease \\
\hline Impaired skin integrity & Altered turgor \\
\hline Disturbed sensory perception & Altered sensory perception \\
\hline $\begin{array}{l}\text { Imbalanced nutrition: More than } \\
\text { body requirements }\end{array}$ & $\begin{array}{l}\text { Excessive food intake regarding } \\
\text { metabolic requirements }\end{array}$ \\
\hline Impaired walking & Birth defects \\
\hline \multirow[t]{2}{*}{ Altered sleep pattern } & Unclear factor \\
\hline & Tissue trauma \\
\hline \multirow[t]{2}{*}{ Chronic pain } & Esophageal cancer effects \\
\hline & Chronic physical disability \\
\hline Acute pain & Harmful agents (biological) \\
\hline
\end{tabular}


Patients with the diagnosis of Deficient knowledge present as related factors lack of exposition (19) and cognitive limitation (1).

The factor related to Tissue trauma was identified in 16 patients who presented diagnosis of Chronic Pain, although the medical diagnoses recorded in the medical records were different: gastroesophageal reflux (6), chagasic and idiopathic megaesophagus (6), and esophageal stenosis and hiatal hernia (1). The factor related to the effects of esophageal cancer was associated to pain in patients who presented a medical diagnosis of esophageal cancer (2). One patient presented a diagnosis of pain associated to chronic physical disability secondary to fibromyalgia.

Of the seven patients in whom the diagnosis of Constipation was identified, one presenting a medical diagnosis of megacolon showed reduced GI tract motility as the defining characteristic.

The defining characteristics of the real diagnoses identified in the study patients were observed in Table 3.

Table 3 - Defining characteristics of the real diagnoses identified in adult patients in the preoperative period of esophageal surgeries. Ribeirão Preto, 2007

\begin{tabular}{|c|c|c|c|}
\hline Diagnostic Category & Características definidoras & Diagnostic Category & Características definidoras \\
\hline \multirow[t]{10}{*}{ Impaired swallowing } & Odynophagia & Nausea & Nausea report \\
\hline & Food refusal & & Food aversion \\
\hline & Nausea & & \\
\hline & Heartburn & Impaired skin integrity & Destruction of skin layers \\
\hline & Food volume limiting & & \\
\hline & Complaints of "something stuck" & Disturbed sensory perception & Time and spatial disorientation \\
\hline & Vomiting & & Altered communication pattern \\
\hline & Epigastric pain & & \\
\hline & Hematemesis & $\begin{array}{l}\text { Imbalanced nutrition: More than } \\
\text { body requirements }\end{array}$ & $\begin{array}{l}\text { Weight } 20 \% \text { over body constitution } \\
\text { and height }\end{array}$ \\
\hline & Regurgitation of gastric contents & & Sedentary activity level \\
\hline $\begin{array}{l}\text { Deficient knowledge regarding the } \\
\text { disease and the preoperative } \\
\text { period }\end{array}$ & Verbalization of the problem & Impaired walking & $\begin{array}{l}\text { Impaired capacity to climb the stairs } \\
\text { and to walk necessary distances }\end{array}$ \\
\hline \multirow[t]{5}{*}{ Anxiety } & Concern & Disturbed sleep pattern & Sleep maintenance insomnia \\
\hline & Insomnia & & $\begin{array}{l}\text { Verbal complaints of not feeling well } \\
\text { restful }\end{array}$ \\
\hline & Report of inadequate food intake & & Sleep dissatisfaction (irritation) \\
\hline & Food intake aversion & & \\
\hline & & Chronic pain & Report of pain for over 6 months \\
\hline \multirow{6}{*}{$\begin{array}{l}\text { Imbalanced nutrition: Less than } \\
\text { body requirements } \\
\text { Constipation }\end{array}$} & $\begin{array}{l}\text { Body weight }>20 \% \text { or lower than } \\
\text { the ideal }\end{array}$ & & Alteration in comfort \\
\hline & Decreased frequency & & Weight loss \\
\hline & Hard and dry stools & & Insomnia \\
\hline & $\begin{array}{l}\text { Straining during bowel movements } \\
\text { (defecation) }\end{array}$ & & \\
\hline & Reduced stool volumes & Acute pain & Verbal report \\
\hline & Abdominal pain & & Food and appetite change \\
\hline
\end{tabular}

Regarding the most frequent defining characteristics observed in the 20 patients with the diagnosis of Impaired Swallowing, the regurgitation of gastric content was identified in 13 patients and epigastric pain in 10 patients.

Imbalanced nutrition: less than body requirements was identified in eight patients and the most frequent defining characteristics were reports of inadequate food intake (6) and body weight $>20 \%$ or lower than the ideal (5). Among seven patients with the diagnosis of Constipation, the most frequent defining characteristics were reduced frequency (7) and hard and dry stools (6).

In Table 4, the risk diagnoses identified along with their related factors are shown. 
Table 4 - Related factors of the risk diagnoses identified in adult patients in the preoperative period of esophageal surgeries. Ribeirão Preto, 2007

\begin{tabular}{cl}
\hline Diagnostic Category & \multicolumn{1}{c}{ Risk Factors } \\
\hline Risk for infection & $\begin{array}{l}\text { Increased environmental exposure to } \\
\text { pathogens } \\
\text { Invasive procedures } \\
\text { Chronic disease } \\
\end{array}$ \\
& Compromised primary defenses \\
& Compromised secondary defenses \\
& Malnutrition \\
Risk for aspiration & Enteral nutrition \\
& Impaired swallowing \\
Risk for trauma & Decreased muscle coordination \\
\hline
\end{tabular}

The most frequently observed risk factors for the 20 patients with the diagnosis of Risk for infection were increased environmental exposure to pathogens (20) and invasive procedures (14). Malnutrition is a risk factor that was established only in case of a medical diagnosis of protein malnutrition or in cases in which the serum albumin test was available and its outcome was lower than $3.5 \mathrm{~g} / \mathrm{dL}$.

\section{DISCUSSION}

We have chosen to discuss those diagnoses with a frequency $\mathrm{e}^{\prime \prime} 50 \%$, and also the aspects related to the defining characteristics and risk factors of these diagnoses. It is observed that these diagnoses reflect the responses presented by the surgical patients with esophageal defects.

The nursing diagnosis of impaired swallowing was identified in the current study in $100 \%$ of the patients. The abnormalities presented by the patients in the preoperative period of esophageal surgeries can compromise swallowing; as an example, we can relate the symptoms related to gastroesophageal reflux, which are regurgitation and epigastric pain ${ }^{(15)}$. In idiopathic megaesophagus, as well as in chagasic megaesophagus, there is a loss of neurons from the esophageal myenteric plexus, leading to the opening of the lower esophageal sphincter, which leads to dysphagia, regurgitation, heartburn, and retrosternal pain $^{(2)}$. In addition, it also leads to difficulties in swallowing, which was presented by the study patients. Dysphagia is a common symptom in patients with esophageal neoplasia, which begins three to four months prior to the diagnosis(2). Difficulties in swallowing lead to regurgitation ${ }^{(16)}$. The defining characteristics observed in the patients are related to the signs and symptoms of the esophageal abnormalities the patients present.

The diagnosis of risk for infection, identified in $100 \%$ of the cases, entailed length of preoperative hospital stay as a risk factor in 12 patients, which favors skin colonization by hospital microbiota. Extremes of nutritional status detected in 14 patients are factors that predispose the patient to infection ${ }^{(17)}$. Another risk factor related to this diagnosis and observed in 15 patients was the performance of invasive procedures with the presence of venous punctures.

Studies surveyed in a literature review addressing nursing diagnoses concerning patients admitted to surgeries in general ${ }^{(4,6-8)}$, have identified the diagnosis of Risk for Infection in more than 50\% of the study patients. Thus, this diagnosis is not specific for this type of surgery, but for patients with increased environmental exposure to pathogens.

Another nursing diagnosis observed in 15 ( $95 \%)$ of the patients was deficient knowledge regarding the disease and perioperative period. Knowledge aboutthe procedures is compromised by several factors, such as the patient's low education level. Many times, the patients come across unknown terms and expressions, insufficient information from the professional involved in care and unprepared professionals to transmit information. The content of preoperative teaching should include some information, such as: surgical preparation according to the procedure type, sequence of events the patient will be submitted to throughout the perioperative period, the expected incision type, surgery time, possibility of preanesthetic medication, function of the several hospital staff members (surgeons, anesthesiologists, nurses, and employees), purpose and main procedures performed at the anesthetic recovery room, accessories and devices/equipment assembled in the intraoperative period, and guidance for patient's rehabilitation at the ward and at home, such as breathing exercises, pain management and early walking. In the current study, 13 patients reported they were not aware of all this information and another six patients say they know only part of the perioperative period and the anesthetic 
procedure. These guidances should be provided by the unit nurse or by the surgery department nurse by means of a preoperative visit.

The diagnosis of chronic pain is defined as: "a state in which the individual presents a persistent or intermittent pattern of pain lasting longer than 6 months"(13). Chronic pain was found in patients with the following symptoms: epigastric pain (10), heartburn (7), dysphagia (7) and odynophagia (3). Patients said they had been presenting these symptoms for some time before seeking medical care, and they underwent clinical treatment before choosing surgery, thus prolonging the painful symptoms. Moreover, one patient complained of pain due to fibromyalgia.

In most studies concerning the preoperative period $^{(4-5,7-8)}$, the diagnosis of anxiety was found in more than $50 \%$ of the patients, which was not supported by the current study. Probably due to a long period of intimacy with the disease and the great discomfort it causes, the news of a surgery can provoke a sensation of relief in the face of the problem resolution, thus minimizing the anxiety to face a surgical intervention. Another hypothesis is that there would be a relationship between the great number of patients who presented the diagnosis of Deficient knowledge and the small number of patients who presented the diagnosis of Anxiety because, although lack of knowledge can lead to anxiety, lack of information can also be a minimizing factor. This is because the patients who have little information regarding the perioperative period are not aware of the risks for undergoing a surgical procedure, or what the postoperative period will be like, and the limitation they are going to be imposed to, such as the time they will have to be fed through a nasogastric catheter.

\section{CONCLUSION}

In the present study, four different nursing diagnoses were identified in patients in the preoperative period of esophageal surgeries with a frequency of more than 50\%; three were real diagnoses and one was a risk diagnosis: Impaired swallowing (100\%), Risk for infection (100\%), Deficient knowledge regarding the disease and the perioperative period (95\%), and Chronic pain (75\%). These diagnoses were analyzed in view of the related factors, defining characteristics or risk factors (according to the type of diagnosis), and the factors associated to the esophageal disease.

Knowing the nursing diagnoses of patients in the preoperative period of esophageal surgeries allow nurses to plan care delivery individually for each client. The identification of the nursing diagnoses allows nurses to establish specific interventions on a scientific basis. The results of the present research can support the implementation of the nursing process for patients in the preoperative period of esophageal surgeries.

\section{REFERENCES}

1. Carpenito LJ. Planos de cuidados de enfermagem e documentação. 2a ed. Porto Alegre (RS): Artmed; 1999.

2. Mincis M. Gastroenterologia \& Hepatologia: diagnóstico e tratamento. 3a ed. São Paulo (SP): Lemos Editorial; 2002.

3. Ponciano H, Cecconello I, Alves L, Ferreira BD, GamaRodrigues J. Cardioplasty and Roux-en-Y partial gastrectomy (Serra-Dória procedure) for reoperation of achalasia. Arq. Gastroenterol. 2004 July-September; 41(3):155-61.

4. Piccoli M, Galvão CM. Enfermagem perioperatória: identificação dos diagnósticos de enfermagem na visita préoperatória fundamentada no Modelo Conceitual de Levine. Cascavel (PR): Edunioeste; 2004.

5. Flório MCS, Galvão CM. Cirurgia Ambulatorial: identificação dos diagnósticos de enfermagem no período perioperatório. Rev Latino-am.Enfermagem 2003 setembro-outubro; 11(5):630-7.

6. Galdeano LE, Rossi LA, Santos CB, Dantas RAS.
Diagnósticos de enfermagem de pacientes no período perioperatório de cirurgia cardíaca. Rev Esc Enfermagem USP 2006 março; 40(1):26-33.

7. Suriano MLF, Barros ALBL. Nursing diagnoses and most frequent interventions during the perioperative period in patients having cardiovascular surgeries. In: Rantz MJ, LeMone $\mathrm{P}$, organizadoras. Classification of Nursing Diagnoses. Proceedings of the Fourteenth Conference. 1 ed. Glendale (CA): North American Nursing Diagnoses Association; 2002. p. 211-4.

8. Andrade AFR. O cuidar do paciente laringectomizado do pré-operatório à reabilitação: o enfermeiro com um modelo assistencial de acordo com os diagnósticos de enfermagem.[dissertação]. São Paulo (SP): Universidade Federal de São Paulo/UNIFESP; 2003.

9. Fontes CMB, Cruz DALM. Cleft lip and palate: pre and post operative nursing diagnoses.. In: Rantz MJ, LeMone P, organizadoras. Classification of Nursing Diagnoses. Proceedings of the Fourteenth Conference. 1 ed. Glendale 
(CA): North American Nursing Diagnoses Association; 2002. p 106-10.

10. Cruz DALM. Os diagnósticos de enfermagem no ensino e na pesquisa. Rev Esc Enferm USP 1992 dezembro; 26(3):427-34

11. Carvalho EC, Jesus CAC. Raciocínio clínico na formulação do diagnóstico de enfermagem para o indivíduo. In: Antunes MJ, Silva MTN, organizadoras. O uso do diagnóstico na prática de enfermagem. Brasília (DF): Associação Brasileira de Enfermagem; 1997. p. 27-38.

12.Dalri CC, Rossi LA, Dalri MCB. Diagnósticos de enfermagem de pacientes em período pós-operatório imediato de colecistectomia laparoscópica. Rev Latino-am Enfermagem 2006 maio-junho; 14(3):389-96.
13. North American Nursing Diagnosis Association. Diagnósticos de enfermagem: definições e classificações. Porto Alegre (RS): Artmed; 2005.

14. Carpenito LJ. Diagnósticos de enfermagem: Aplicação à prática clinica. 10 ed. Porto Alegre (RS): Artmed; 2005.

15. Oliveira SS, Santos IS, Silva JFP, Machado EC. Gastroesophageal reflux disease: prevalence and associated factors. Arq Gastroenterol 2005 June; 42(2):116-21.

16. Spence RAJ, Johnstons PG. Oncologia. Rio de Janeiro (RJ): Guanabara Koogan; 2003.

17. Rodrigues EAC, Mendonça JS, Amarante JMB, Alves MBF, Grinbaum RS, Ritchtmann R. Infecções Hospitalares: prevenção e controle. São Paulo (SP): Sarvier; 1997. 